\title{
PENGARUH POLA ASUH ORANG TUA TERHADAP KEMAMPUAN PENGAMBILAN KEPUTUSAN MAHASISWA PRIA ETNIS SUMBA DI SALATIGA
}

\author{
Melinda Sureti Rambu Guna ${ }^{1}$, Tritjahjo Danny Soesilo ${ }^{2}$, Yustinus Windrawanto $^{3}$ \\ email: melindarambu@gmail.com ${ }^{1}$ \\ Program Studi Bimbingan dan Konseling, Fakultas Keguruan dan Ilmu Pendidikan \\ Universitas Kristen Satya Wacana ${ }^{1,2,3}$
}

\begin{abstract}
Abstrak
Penelitian ini bertujuan untuk mengetahui signifikansi pengaruh pola asuh orang tua terhadap kemampuan pengambilan keputusan mahasiswa pria etnis Sumba di Salatiga.Jenis penelitian ini adalah penelitian kuantitatif. Pengambilan sampel menggunakan metode probability sampling, sedangkan cara pengambilan sampel yang digunakan adalah simple random sampling. Pengumpulan data menggunakan dua jenis instrumen, untuk instrumen yang pertama pola asuh orang tua dikembangkan berdasarkan teori dari Hurlock, diadopsi dari Riza (2012) dan instrumen yang kedua pengambilan keputusan yang dikembangkanberdasarkan teori dari John Krumboltz diadopsi dari Rifal (2013). Teknik analisis data yang digunakan adalah Simple Linear Regression. Pengolahan data menggunakan progam SPSS for Windows 16.0 version. Hasil penelitian menunjukkan bahwa ada pengaruh yang signifikan pola asuh orang tua terhadap kemampuan pengambilan keputusan mahasiswa pria etnis Sumba di Salatiga. Hal ini dibuktikan dengan perolehan nilai $\mathrm{T}$ hitung = 0,749 , lebih besar nilai $\mathrm{T}$ tabel $=0,677$.
\end{abstract}

Kata Kunci: Pola Asuh; Pengambilan Keputusan

\begin{abstract}
This study aims to determine the significance of the influence of parenting on the decision-making abilities of Sumba ethnic male students in Salatiga. This type of research is quantitative research. Sampling uses probability sampling method, while the sampling method used is simple random sampling. The data collection uses two types of instruments, for the first instrument parents' parenting was developed based on the theory of Hurlock, adopted from Riza (2012) and the second instrument of decision making developed based on the theory of John Krumboltz adopted from Rifal (2013). The data analysis technique used is Simple Linear Regression. Processing data using the SPSS program for Windows 16.0 version. The results showed that there was a significant effect of parenting on the decision-making abilities of Sumba ethnic male students in Salatiga. This is evidenced by the acquisition of T count $=0.749$, the greater the value of T table $=0.677$.

Keywords: Parenting; Decision-making
\end{abstract}

\section{PENDAHULUAN}

Pendidikan adalah usaha sadar yang dilakukan oleh keluarga, masyarakat, dan pemerintah melalui kegiatan bimbingan, pengajaran atau latihan yang berlangsung di Sekolah dan di luar sekolah sepanjang hayat, untuk mempersiapkan peserta didik agar dapat memainkan peranan dalam berbagai lingkungan hidup secara tepat di masa yang akan datang (Redja Mudyahardjo, 2012).
Keluarga merupakan lingkungan pendidikan dasar yang pertama dan yang utama, karena dalam keluarga anak pertama-tama mendapatkan didikan dan bimbingan yang menjadi dasar dalam pembentukan diri anak.Juga dikatakan lingkungan yang utama, karena sebagian besar dari kehidupan anak adalah didalam keluarga, sehingga pendidikan yang paling banyak diterima oleh anak adalah dalam keluarga (Hasbullah, 2005). 
Menghadapi berbagai macam tantangan di era sekarang ini orang tua sangat diharapkan mampu menerapkan pola asuh yang sesuai pada anak. Dengan menerapkan berbagai cara sebagai contoh yang baik serta memberikan dukungan kepada anak dalam mengembangkan bakat dan minat yang dimilikinya. Pola asuh orang tua itu sendiri adalah suatu cara terbaik yang dapat ditempuh orang tua dalam mendidik anaknya sebagai wujud dari rasa tanggung jawab kepada anak (Desmita, 2013).

Keluarga mempunyai pengaruh besar dalam membentuk karakter dan kepribadian anak. Berbagai bentuk dan isi serta cara-cara pendidikan di dalam keluarga akan selalu mempengaruhi tumbuh dan berkembangnya watak, budi pekerti, dan kepribadian tiap-tiap manusia (Fuad Ihsan, 2001). Tabiat, tindakan, kerja keras, kreatif, mandiri, demokratis, tanggung jawab, dan sebagainya tidak lepas dari peran keluarga. Pengambilan keputusan diharapkan dapat ditumbuhkan dan ditingkatkan pada anak melalui pengasuhan yang baik oleh orang tua.

Proses pengambilan keputusan adalah sebuah proses untuk mencapai satu kesimpulan yang didahului oleh serangkaian pertimbangan yang menghasilkan dipilihnya satu kemungkinan serta dikesampingkannya kemungkinan-kemungkinan lain (Morgan dan Cerullo, (dalam Salusu, 2015).

Pada proses pengambilan keputusan, seseorang menentukan pilihan yang akan dilakukannya untuk mencapai suatu tujuan, khususnya dalam menentukan studi lanjut dijenjang pendidikan yang lebih tinggi. Pendidikan merupakan salah satu bagian penting dalam kehidupan seorang anak, di mana seorang anak memiliki peran penting dalam memutuskan pilihan jurusan yang sesuai dengan minat dan bakatnya.

Dalam daerah tertentu, khususnya dalam suku di Sumba, yang dimana terbagi atas empat kabupaten, Sumba Barat Daya, Sumba Barat, Sumba Tengah dan Sumba Timur dengan sepuluh suku utama yang dimana terdapat berbagai macam ciri khas orang tua dalam mendidik anak-anaknya khususnya pada kaum pria. Pria suku Sumba pada umumnya senantiasa menjadi anak yang sangat dibanggakan oleh orang tua dan keluarga besarnya. Dalam hal ini pria suku di Sumba senantiasa cenderung sangat sulit dalam menentukan serta mengambil satu langkah lebih baik dalam pengambilan keputusannya. Hal ini dikarenakan hubungan kekeluargaan yang sangat erat, sehingga sangat 
berpengaruh pada pengambilan keputusan kaum pria.

Mengingat bahwa hak warisan kedepannya berada dalam kekuasaan pria sebagai budaya yang menjadi turun temurun sehingga menjadi suatu kebiasaan. Misalnya: ketika pria yang tinggal dan besar dalam keluarga yang memiliki fasilitas yang memadai seperti berkecukupan dalam segi perekonomian, seringkali menjadi kebiasaan bagi para orang tua untuk tetap mempertahankan semua yang dimilki dengan beranggapan bahwa anaknya dalam hal ini kaum pria harus senantisa ikut serta dalam mempertahankan itu semua, sehingga dalam hal mengambil suatu keputusan pria bergantung pada apa yang menjadi keputusan orang tuanya.

Prinsipnya bahwa semua didikan yang diberikan orang tua adalah baik bagi anaknya, akan tetapi seringkali orang tua tidak menyadari bahwa berbagai macam pola asuh orang tua sangat berdampak bagi pengambilan keputusan seorang anak, karena tidak sesuai dengan kemampuan dan bakat minat dari anak itu sendiri.

Beberapa penelitian relevan sebelumnya oleh Raihanal Miski, Marty Mawarpury (2017) dengan judul :Pengambilan Keputusan Pada Remaja Yang Mengalami Pengasuhan Otoriter.
Hasil penelitian menunjukkan terdapat pengaruh pengasuhan otoriter terhadap pengambilan keputusan subjek yang ditunjukkan dengan adanya tuntutan dan keterlibatan orangtua dalam proses pengambilan keputusan namun subjek tidak merasa terbebani berusaha memikirkan makna positif dari tuntutan yang diterima.

Penelitian selanjutnya oleh Heni Indriyanti (2014), dengan judul Pola Asuh Anak Dalam Keluarga Masyarakat Suku Samin (Studi Kasus Desa Klopoduwur). Hasil penelitian menunjukan bahwa pola asuh yang diterapkan orang tua masyarakat suku samin ialah pola asuh demokratis yang memberi kebebasan pada anaknya namun orang tua tidak melepaskan akan tanggung jawabnya sebagai orang tua.

Penelitian oleh Olisiani Ndua Rama (2014), dengan judul: Hubungan Antara Kecenderungan Pola Asuh Authoritarian Orang Tua Dengan Konsep Diri Pada Remaja Kelas XII SMA Kristen Payeti di Sumba Timur. Hasil penelitian menunjukan tidak ada hubungan negatif dan signifikan antara kecenderungan pola asuh authoritarian orang tua dengan konsep diri remaja kelas XII SMA Kristen Payeti di Sumba Timur dengan koefisien korelasi (r) sebesar -0,121 
dengan signifikansi sebesar 0,147 (p > $0,05)$.

Berdasarkan uraian di atas penulis melihat bahwa pendidikan dalam keluarga mempunyai peran yang sangat strategis dan amat menentukan pencapaian mutu sumber daya manusia. Dalam penyelenggaraan pendidikan khususnya bagi orang tua etnis Sumba keluarga tidak sekedar berperan sebagai pelaksana yang bersifat rutin dan alamiah, melainkan berperan sebagai pengelola yang bertanggung jawab dalam meletakkan landasan dan memberikan bobot dan pola-pola kehidupan bagi anak. Akan tetapi hal tersebut menajdikan pola asuh pada orang tua etnis Sumba cenderung bersifat otoriter. Pola asuh otoriter akan berdampak pada diri anak serta memicu munculnya permasalahan baru.

Hal inilah yang menjadi alasan penulis ingin melakukan penelitian dimana penulis melihat bahwa pola asuh yang diterapkan orang tua Sumba, khususnya pola asuh otoriter tentu saja akan mengakibatkan masalah dikemudian hari, karena apabila mahasiswa dipaksakan untuk mengambil keptutusan hanya karena paksaan orang tua mereka akan mengalami dampak negatif seperti, malas-malasan, stress, putus asa, tidak memiliki motivasi untuk belajar, kehilangan gairah kuliah bahkan tidak jarang justru berakhir dengan drop out dari perguruan tinggi tersebut.

\section{KAJIAN PUSTAKA}

\section{Pengambilan Keputusan}

Salah satu bagian penting dan tidak dapat dihindari dalam kehidupan manusia adalah mengambil berbagai keputusan. Bahkan didalam sehari manusia bisa saja dapat membuat beberapa keputusan sekaligus, baik secara disadari maupun tidak disadari. Keputusan adalah bagian dari hasil yang menjatuhkan pilihan diantara dua atau lebih banyak alternatif jalan keluar dalam berbagai situasi permasalahan yang ada, baik dari mencari jalan keluar sampai dengan melakukan tindakan penyelesaian yang akurat (I. Gede Pranaseto, 2003).

Siagian (1980) menjelaskan bahwa proses pengambilan keputusan adalah suatu hasil keluaran atau pendekatan terstruktur/sistematis terhadap hakikat suatu masalah, dimana dengan proses pengumpulan berbagai fakta-fakta nyata dan data yang akurat, sebagai salah satu penentuan yang matang dari berbagai alternatif yang akan dihadapi dan pengambilan tindakan yang menurut perhitungan merupakan tindakan yang paling tepat untuk diambil. Sedangkan, Iqbal Hasan (2002) menjelaskan bahwa pengambilan keputusan itu sendiri 
merupakan suatu proses pemilihan satu alternatif terbaik dari beberapa alternatif yang ada secara sistematis/terstruktur untuk ditindak lanjuti (digunakan) sebagai suatu cara pemecahan masalah.

John Krumboltz mengemukakan dalam Taksonomi Krumboltz ada lima gaya pegambilan keputusan karir yang sangat mempengaruhi dalam pengambilan keputusan karir yaitu: rational, fatalistic, intuitive, impulsive, and dependent (Greenhaus dan Callanan, 2006).Terry (dalam Iqbal Hasan, 2002) menyebutkan lima dasar penting yang digunakan dalam proses pengambilan keputusan, yaitu:

1. Pengambilan keputusan berdasarkan intuisi

2. Pengambilan keputusan berdasakan pengalaman

3. Pengambilan keputusan berdasarkan fakta

4. Pengambilan keputusan berdasarkan wewenang

5. Pengambilan keputusan rasional

Menurut Krumboltz (dalam Munandir, 1996) menjelaskan empat kategori faktor yang mempengaruhi pengambilan keputusan seseorang. Faktor-faktor tersebut adalah kondisi lingkungan, genetik, belajar, dan keterampilan menghadapi tugas atau masalah. Penjabaran dari keempat faktor tersebut adalah sebagai berikut:

1. Kondisi lingkungan

Lingkungan berpengaruh pada pengambilan keputusan seperti kesempatan, kebijakan pemerintah, aturan-aturan, peristiwa alam, imbalan material atau penghargaan sosial, sumber alam, kemajuan teknologi, perubahan sosial, keluarga, sistem (pemerintahan, pendidikan), lingkungan masyarakat. Faktor-faktor ini berada di luar kendali individu, namun memiliki pengaruh signifikan terhadap pengambilan keputusan.

2. Genetik

Faktor ini dibawa dari lahir berupa kondisi fisik seperti wajah, jenis kelamin, suku bangsa, dan kekurangan fisik. Kondisi seseorang bisa membatasi keputusannya untuk menyusun suatu rencana yang penting dalam kehidupannya. Misalnya, seperti pengambilan keputusan untuk memilih suatu pekerjaan, atau pendidikan tertentu yang akan ditekuni. Kemampuan lainnya yang juga dibawa secara genetik adalah kecerdasan dan bakat.

3. Belajar

Pengalaman belajar mempengaruhi tingkah laku dan putusan. 
Pengalaman belajar setiap orang berbeda-beda. Belajar dibagi menjadi dua, yaitu belajar instrumental dan asosiatif. Belajar instrumental yaitu belajar melalui pengalaman langsung, meresponnya dan mendapatkan konsekuensi dari hasil belajarnya. Belajar asosiatif yaitu belajar dengan mengaitkan hubungan antara kejadian-kejadia dan memprediksi konsekuensinya.

4. Keterampilan menghadapi tugas atau masalah

Keterampilan ini dicapai melalui interaksi antara pengalaman belajar, genetik, kemampuan khusus dan lingkungan. Keterampilan ini diterapkan untuk menghadapi dan menyelesaikan tugas-tugas baru. Keterampilan menghadapi tugas ini merupakan hasil belajar dan keterampilan yang diperoleh sebelumnya. Salah satu contohnya adalah keterampilan dalam proses pengambilan keputusan.

\section{Pola asuh Orang Tua}

Dalam kehidupan sehari-hari dirumah, seperti telah diketahui terdapat bermacam-macam pola pendidikan atau pola asuh yang diterapkan oleh orang tua. Pengasuhan orang tua atau yang lebih dikenal dengan pola asuh orang tua, menurut Casmini (2007) yaitu bagaimana orang tua memperlakukan anak, mendidik, membimbing dan mendisiplinkan serta melindungi anak dalam mencapai proses kedewasaan, hingga kepada upaya pembentukan norma-norma yang diharapkan oleh masyarakat secara umum.

Menurut Chabib Thoha (1996) pola asuh orang tua adalah suatu cara terbaik yang dapat ditempuh orang tua dalam mendidik anak sebagai perwujudan dari rasa tanggung jawab kepada anak. Jika pendidikan dalam keluarga dapat berlangsung dengan baik maka mampu menumbuhkan perkembangan kepribadian anak menjadi manusia dewasa yang memiliki sikap positif terhadap agama, kepribadian yang kuat dan mandiri, potensi jasmani dan rohani serta intelektual yang berkembang secara optimal.

Djamarah (2014) berpendapat bahwa pola asuh orang tua dalam keluarga berarti kebiasaan orang tua, ayah dan atau ibu, dalam memimpin, mengasuh, dan membimbing anak dalam keluarga. Pola asuh orang tua merupakan pola perilaku yang diterapkan pada anak dan bersifat relatif konsisten dari waktu ke waktu. Pola perilaku ini dapat dirasakan oleh anak dan bisa memberi efek negatif maupun positif. 
Menurut Diana Baumrind (Bee \& Boyd, 2004), terdapat 4 aspek dalam pola asuh yang diterapkan oleh orang tua, yaitu:

1. Kendali dari orang tua (Parental control)

2. Tuntutan terhadap tingkah laku matang (Parental maturity demands)

3. Komunikasi antara orang tua dan anak (Parent-child communication)

4. Cara pengasuhan atau pemeliharaan orang tua terhadap anak (Parental nurturance)

Hurlock (1999) membagi bentuk pola asuh orang tua menjadi 3 bentuk pola asuh orang tua yaitu:

1. Pola Asuh Demokratis

Pola asuh demokratis merupakan pola asuh yang dipandang paling baik. Pada pola asuh ini, orangtua bersikap kooperatif dan mendorong anak untuk mandiri namun tetap memberikan batasan dan kendali terhadap tindakan anak. Dalam keluarga orang tua senantiasa bersifat hangat dan mengasuh, sehingga komunikasi tetap terjalin secara dua arah, nyaman dan adil.

2. Pola Asuh Otoriter

Pengasuhan dengan gaya seperti ini bersifat membatasi dan menghukum, orangtua tidak kooperatif, menerapkan aturan yang kaku, banyak menuntut anak tanpa memberikan kesempatan anak untuk mengutarakan pendapatnya. ini menempatkan orangtua sebagai pusat dan pemegang kendali karena orang tua orang tua melakukan kontrol yang ketat terhadap anak.

3. Pola Asuh Permisif

Pengasuhan dengan gaya seperti ini bersikap kurang perduli terhadap anaknya, kurang memberi perhatian, melepaskan kontrol terhadap anak, dan membiarkan anak untuk melakukan apapun sesuka hatinya tanpa ada keterlibatan dari orangtua untuk mengarahkannya. Orang tua kurang melakukan evaluasi dan kontrol terhadap perilaku anak. Orangtua senantiasa mengikuti keinginan anak.

Hurlock (1997) menjelaskan beberapa faktor yang dapat mempengaruhi pola asuh orangtua,yaitu sebagai berikut:

1. Tingkat sosial ekonomi

Orangtua yang tingkat sosial ekonominya menengah seringkali akan lebih banyak bersikap hangat dibandingkan orangtua yang berasal dari sosial ekonomi yang rendah.

2. Tingkat pendidikan

Latar belakang pendidikan orang tua yang lebih tinggi dalam praktek asuhannya terlihat lebih sering 
membaca artikel ataupun mengikuti perkembangan pengetahuan mengenai perkembangan anak. Dalam mengasuh anaknya, mereka menjadi lebih siap karena memiliki pemahaman yang lebih luas, sedangkan orangtua yang memiliki latar belakang pendidikan terbatas, memiliki pengetahuan dan pengertian yang terbatas mengenai kebutuhan dan perkembangan anak sehingga kurang menunjukan pengertian dan cenderung akan memperlakukan anaknya dengan ketat dan otoriter.

3. Kepribadian

Kepribadian orangtua dapat mempengaruhi penggunaan pola asuh. Orangtua yang konservatif cenderung akan memperlakukan anaknya dengan ketat dan otoriter.

4. Jumlah anak

Orangtua yang memiliki anak hanya 2-3 orang (keluarga kecil) cenderung lebih intensif pengasuhannya, dimana interaksi antara orangtua dan anak lebih menekankan pada perkembangan pribadi dan kerja sama antar anggota keluarga lebih diperhatikan. Orangtua yang memiliki anak berjumlah lebih dari lima orang (keluarga besar) sangat kurang memperoleh kesempatan untuk mengadakan kontrol secara intensif antara orangtua dan anak karena orangtua secara otomatis berkurang perhatiannya pada setiap anak.

Santrock (2012) juga menyebutkan beberapa faktor yang mempengaruhi dalam pola pengasuhan, antara lain:

1. Pewarisan metode pola asuh yang didapat sebelumnya. Orangtua senantiasa menerapkan pola pengasuhan kepada anak berdasarkan pola pengasuhan yang pernah didapat sebelumnya.

2. Perubahan budaya, yaitu perubahan norma dan adat istiadat antara dulu dan sekarang.

Setiap faktor yang mempengaruhi pola asuh ternyata saling berkaitan satu dengan yang lainnya. Jika salah satu faktor sudah ada yang bermasalah, maka akan memicu munculnya masalah dalam pola pengasuhan dalam keluarga.

\section{METODE PENELITIAN}

Jenis penelitian yang digunakan adalah penelitian kuantitatif.Penelitian kuantitatif adalah jenis penelitian yang digunakan untuk menjawab permasalahan melalui teknik pengukuran yang cermat terhadap variabel-variabel tertentu, sehingga menghasilkan simpulansimpulan yang dapat digeneralisasikan, lepas dari konteks waktu dan situasi serta 
jenis data yang dikumpulkan terutama data kuantitatif (Zainal Arifin, 2012).

Ditinjau dari metode yang dipakai, maka penelitian ini termasuk dalam penelitian ex-post facto karena mengungkapkan data yang sudah berlangsung dan telah ada pada responden tanpa memberikan perlakuan atau manipulasi apapun. Metode penelitian ini merupakan proses penelitian yang dapat dilaksanakan dengan mengambil sampel dari suatu populasi dan menggunakan angket (kuesioner) sebagai salah satu alat pengumpul data pokok.

Pada penelitian ini pengambilan sampel yang digunakan adalah simple randomsampling, dengan bayaknya sampel yang digunakan adalah 50 sampel. Pengumpulan data menggunakan dua jenis instrumen, untuk instrumen yang pertama pola asuh orang tua dikembangkan berdasarkan teori dari Hurlock dan instrumen yang kedua pengambilan keputusan yang dikembangkanberdasarkan teori dari John Krumboltz.

Teknik analisis data dalam penelitian kuantitatif menggunakan statistik. Tindakan yang berupa kegiatan dalam proses analisis data yaitu meliputi proses mengelompokkan data berdasarkan variabel dan jenis responden, mentabulasi data dapat berdasarkan variabel dari seluruh responden, menyajikan data tiap variabel yang diteliti, melakukan perhitungan untuk menjawab rumusan masalah, dan melakukan perhitungan untuk menguji hipotesis yang telah diajukan(Sugiyono, 2013). Penelitian ini menggunakan teknik analisis Regresi Linier Sederhana (Simple Linear Regression) untuk mengetahui seberapa berpengaruh variabel bebas terhadap variabel terikat.

\section{HASIL PENELITIAN}

Hasil penelitian ini dianalisis berdasarkan pada fakta pola asuh orang tua dan kemampuan pengambilan keputusan pada mahasiswa pria etnis Sumba di Salatiga.

Tabel 1. Kemampuan Pengambilan Keputusan

\begin{tabular}{|c|c|c|c|c|}
\hline No & Kategori & Interval & Frekuensi & Persentase (\%) \\
\hline 1. & Sangat tinggi & $100-123$ & 10 & $20 \%$ \\
\hline 2. & Tinggi & $77-99$ & 34 & $68 \%$ \\
\hline 3. & Rendah & $54-76$ & 4 & $8 \%$ \\
\hline 4. & Sangat rendah & $31-53$ & 2 & $4 \%$ \\
\hline \multicolumn{3}{|c|}{ Total } & 50 & 100 \\
\hline
\end{tabular}

Tabel 2. Pola Asuh Orang Tua

\begin{tabular}{|l|l|c|c|}
\hline No & Pola Asuh & Frekuensi & Persentase (\%) \\
\hline 1. & Otoriter & 25 & $50 \%$ \\
\hline 2. & Demokratis & 19 & $38 \%$ \\
\hline 3. & Permisif & 6 & $12 \%$ \\
\hline \multicolumn{2}{|c|}{ Total } & $\mathbf{5 0}$ & $\mathbf{1 0 0 \%}$ \\
\hline
\end{tabular}


Tabel 3. Model Summary

\begin{tabular}{|l|r|r|r|r|}
\hline Model & \multicolumn{1}{c|}{$\mathrm{R}$} & $\mathrm{R}$ Square & \multicolumn{1}{|c|}{$\begin{array}{c}\text { Adjusted } \mathrm{R} \\
\text { Square }\end{array}$} & $\begin{array}{r}\text { Std. Error of } \\
\text { the Estimate }\end{array}$ \\
\hline 1 & $.108^{\mathrm{a}}$ & .012 & -.009 & 14.968 \\
\hline
\end{tabular}

a. Predictors: (Constant), POLA ASUH

Berdasarkan data Model Summary di atas dapat diketahui bahwa nilai dari $\mathrm{R}$ Squarenya adalah 0,012 yang berarti 1,2 $\%$. Jadi dapat disimpulkan bahwa variabel pola asuh memberikan pengaruh terhadap pengambilan keputusan hanya sebesar $1.2 \%$. dan untuk 98,8\% oleh faktor lain yang tidak dijelaskan dalam penelitian ini.

\section{Tabel 5. Uji Hipotesis}

\begin{tabular}{|c|c|c|c|c|c|}
\hline \multirow[b]{2}{*}{ Model } & \multicolumn{2}{|c|}{$\begin{array}{c}\text { Unstandardized } \\
\text { Coefficients }\end{array}$} & \multirow{2}{*}{\begin{tabular}{|c|}
$\begin{array}{c}\text { Standardized } \\
\text { Coefficients }\end{array}$ \\
Beta
\end{tabular}} & \multirow[b]{2}{*}{$\mathrm{t}$} & \multirow[b]{2}{*}{ Sig. } \\
\hline & B & Std. Error & & & \\
\hline $\begin{array}{ll}1 & \text { (Constant) } \\
& \text { POLA } \\
& \text { ASUH }\end{array}$ & $\begin{array}{r}79.534 \\
.105\end{array}$ & 12.624 & .108 & 6.300 & .000 \\
\hline
\end{tabular}

a. Dependent Variable: PENGAMBILAN KEPUTUSAN

Berdasarkan data Coefficients yang adalah hasil uji t (secara parsial), diatas dapat diketahui bahwa $\mathrm{T}$ hitung pola asuh $=0,749$. Dengan tingkat signifikansi 0.05 dan dk (derajat kebebasan) n2 yaitu 50 $2=48$ dengan menggunakan uji dua fihak sehingga nilai $\mathrm{T}$ tabel $=0,677$, karena nilai $\mathrm{T}$ hitung lebih besar dari $\mathrm{T}$ tabel $(0,749>0,677$,$) . Artinya, ada$ pengaruh yang sigifikan pola asuh orang tua terhadap kemampuan pengambilan keputusan pada mahasiswa pria etnis Sumba di Salatiga.

\section{PEMBAHASAN}

Pola asuh orang tua mempunyai peranan terhadap perkembangan anak. Ravik Karsidi (2008) menyatakan bahwa keluarga merupakan lingkup kehidupan yang paling berpengaruh terhadap perjalanan seorang individu serta dalam membimbing anak dalam setiap proses pengambilan keputusan, karena anak senantiasa bergantung pada ciri yang melekat pada keluarga. Pengasuhan yang baik menimbulkan persepsi yang baik pada diri anak. Persepsi yang baik akan memudahkan dalam mengambil suatu keputusan yang hangat antara orang tua dan anak. Keterbukaan diperlukan antara orang tua dan anak agar kedua belah pihak saling mengerti satu sama lain. Orang tua menyayangi dan mengasihi serta anak yang patuh dan hormat kepada orang tua. Orang tua dan anak yang harmonis akan membuat semua pihak mengerti dengan hak dan kewajiban masing-masing.

Hasil penelitian diketahui bahwa bahwa variabel pola asuh orang tua diatas menunjukkan bahwa tipe pola asuh orang tua otoriter terdapat 25 mahasiswa (50\%), tipe pola asuh orangtua demokratis terdapat 19 mahsiswa (38\%) dan yang memiliki tipe pola asuh permisif terdapat 
6 mahasiswa (12\%). Jadi dari 50 mahasiswa pria etnis Sumba di Salatiga sebagian besar orang tua menerapkan pola asuh orang tua otoriter.

Pada variabel pengambilan keputusan mahasiswa pria etnis Sumba di Salatiga yang berjumlah 50 mahasiswa diperoleh hasil: sebanyak 34 mahasiswa (68\%) berada pada kategori tinggi, 10 mahasiswa (20\%) berada pada kategori sangat tinggi, 4 mahasiswa (8\%) berada pada kategori rendah, dan 2 mahasiswa (4\%) berada pada kategori sangat rendah.

Masalah yang ingin diungkap dalam penelitian ini adalah apakah ada tidaknya pengaruh signifikansi antara pola asuh orang tua terhadap kemampuan pengambilan keputusan pada mahasiswa pria etnis Sumba di Salatiga. Berdasarkan data yang diperoleh dari hasil penelitian kemudian diolah dengan menggunakan program SPSS windows versi 16.0.

Hasil penelitian yang dilakukan, menunjukkan bahwa ada pengaruh yang signifikan antara pola asuh orang tua terhadap kemampuan pengambilan keputusan pada mahasiswa pria etnis Sumba di Salatiga dengan memperoleh nilai $\mathrm{t}$ hitung > dari $\mathrm{t}$ tabel ( $0,749>$ 0,677). Hal ini membuktikan bahwa terdapat pengaruh secara signifikan pola asuh terhadap kemampuan pengambilan keputusan.

Penelitian ini sejalan dengan penelitian Raihanal Miski, Marty Mawarpury (2017) dengan judul :Pengambilan Keputusan Pada Remaja Yang Mengalami Pengasuhan Otoriter. Hasil penelitian menunjukkan terdapat pengaruh pengasuhan otoriter terhadap pengambilan keputusan subjek yang ditunjukkan dengan adanya tuntutan dan keterlibatan orangtua dalam proses pengambilan keputusan namun subjek tidak merasa terbebani berusaha memikirkan makna positif dari tuntutan yang diterima.

Hasil penelitian ini secara implisit menyatakan bahwa ada pengaruh yang signifikan pola asuh terhadap kemampuan pengambilan keputusan. Peneitian menunjukkan bahwa sebagian besar mahasiswa pria etnis Sumba di Salatiga memiliki tingkat pola pengasuhan yang otoriter dalam mengambil suatu keputusan.

Dari data yang telah terkumpul diketahui bahwa tidak ada satupun pria etnis Sumba yang memiliki orang tua dengan pola asuh tertentu secara mutlak. Artinya data yang terlampir tidak satupun responden yang memilih jawaban otoriter seluruhnya, demokratis seluruhnya serta permisif seluruhnya. Ini menandakan 
tidak adanya pola asuh murni yang diterapkan oleh orang tua kepada anak. Dengan demikian, jika alternatif pilihan pria etnis Sumba paling banyak pada pola asuh otoriter berarti pola pengasuhan orang tua Sumba cenderung menerapkan pola asuh otoriter, jika alternatif pilihan paling banyak demokratis, maka pola pengasuhan orang tua Sumba cenderung menerapkan pola asuh demokratis, dan jika pilihan paling banyak jawaban permisif berarti pola pengasuhan orang tua cenderung menerapkan pola asuh permisif. Dengan demikian pola asuh otoriter, demokratis serta permisif akan ada pada kebanyakan orang tua, serta yang membedakan adalah tingkatan atau intensitasnya.

\section{KESIMPULAN}

Berdasarkan hasil penelitian dapat disimpulkan bahwa ada pengaruh yang signifikan pola asuh orang tua terhadap kemampuan pengambilan keputusan pada mahasiswa pria etnis Sumba di Salatiga. Hal ini dibuktikan dengan perolehan nilai $\mathrm{t}$ hitung > dari t tabel $(0,749>$ 0,677).Berdasarkan hasil penelitian, mahasiswa pria etnis Sumba memiliki rata-rata tingkat pengambilan keputusan tinggi.

Peneliti memberi saran agar terus mempertahan tingkat pengambilan keputusan yang tinggi tersebut bahkan meningkatkannya lagi, menggunakan kemampuan kritis serta pemahaman diri individu yang matang, sehingga dalam proses pengambilan keputusan senantiasa haruslah sang pengambil keputusan adalah orang yang sangat mengerti kehidupannya sendiri, kemampuannya, bakat-mintanya serta bijaksana dalam menentukan pilihan yang baik bagi masa depannya.

Berdasarkan hasil penelitian ini, dapat dilihat bahwa pola asuh orang tua bukanlah satu-satunya faktor yang mempengaruhi pengambilan keputusan. Tidaklah salah bagi setiap orang tua dalam menerapkan pola asuh yang berbeda-beda pada anak. Sebaiknya orang tua lebih memperhatikan dan memahami perilaku anak dan dampaknya pada anak dari pola asuh yang diterapkan. Orang tua juga harus memperhatikan halhal lainnya yang dapat mempengaruhi pengambilan keputusan anak terutama dalam menentukan pilihan masa depan.

\section{DAFTAR PUSTAKA}

Arifin, Zainal. 2012. Evaluasi Pembelajaran. Bandung: PT. Remaja Rosdakarya.

Casmini. 2007. Emotional Parenting. Yogyakarta :PilarMedika.

Desmita. 2013. Psikologi Perkembangan Peserta Didik. Bandung: PT RemajaRosdakarya.

Djamarah, Syaiful Bahri. 2014. Pola Asuh Orang Tua dan Komunikasi 
dalamKeluarga. Jakarta: Rineka Cipta.

Fuad, Ihsan. 2001. Dasar-Dasar Kependidikan. Jakarta: PT Rineka Cipta.

Greenhaus, J \& Callanan, G.2006.Encyclopedia of Career Development. California: SAGE Publications, inc.

Hasbullah, 2005.Dasar-dasar Ilmu Pendidikan. Jakarta: PT Raja GrafindoPersada.

Hasan Iqbal. 2002. Pokok-pokok Materi $\begin{array}{lll}\text { Statistik } & 2 & \text { (Statistik }\end{array}$ Inferensi).Jakarta Penerbit Bumi Aksara.

Heni, Indriyanti. 2014. Pola Asuh Anak Dalam Keluarga Masyarakat Suku Samin (Studi Kasus Desa Klopoduwur).

Hurlock, Elizabeth B. 1997. Psikologi Perkembangan: Suatu PendekatanSepanjang Rentang Kehidupan. Jakarta: Erlangga (Edisi kelima)

Mudyahardjo, Redja. 2012. Pengantar Pendidikan Sebuah Setudi Awal Tentang Dasar-Dasar Pendidikan Pada Umumnya Dan Pendidikan Indonesia. Jakarta : Rajagrafindo persada.

Munandir. 1996. Program Bimbingan Karir di Sekolah. Jakarta: Depdikbud.

Olisiani Ndua Rama. 2014. SKRIPSI: Hubungan Antara Kecenderungan Pola Asuh Authoritarian Orang Tua Dengan Konsep Diri Pada Remaja Kelas XII SMA Kristen Payeti di Sumba Timur.

P. Siagian, Sondang. 1980. Sistem Informasi: Untuk Pengambilan Keputusan. Jakarta: Gunung Agung
Pranaseto, I. G. 2003. Cara Jitu Membuat Keputusan. Jakarta: Progres

Raihanal Miski, Marty Mawarpury. 2017. Pengambilan Keputusan Pada Remaja Yang Mengalami Pengasuhan Otoriter. Jurnal Ecopsy, Volume 4 Nomor 3, Desember 2017.

Ravik, Karsidi. 2008. Sosiologi Pendidikan. Surakarta: LPP UNS dan UNS Press.

Salusu, J. 2015. Pengambilan Keputusan Stratejik Untuk Organisasi Publik dan Organisasi Nonprofit. Grasindo: Jakarta.

Santrock, John W. 2012. Life-Spand Development. Perkembangan Masa Hidup. Jakarta: Erlangga (Edisi ketiga belas).

Sugiyono. 2013. Metode Penelitian Pendidikan Pendekatan Kuantitatif, Kualitatif, dan $R \& D$. Bandung: Alfabeta.

Thoha, Chabib. 1996. Kapita Salekta Pendidikan Islam.Yogyakarta: Pustaka Belajar. 